\title{
Mixing Body and Soul: Galen on the Substance of Soul in QAM and De Propriis Placitis
}

\author{
Robert Vinkesteijn \\ Department of Philosophy and Religious Studies, Utrecht University, \\ Janskerkhof 13, 3512 BL Utrecht. The Netherlands \\ robertvinkesteijn@live.nl
}

\begin{abstract}
In a late treatise, That the Capacities of the Soul Follow the Mixtures of the Body (QAM), Galen of Pergamum infamously offered the view that the substance of the soul is identical with a bodily mixture. This thesis has been found radical and extreme in modern scholarship and is generally considered to be at odds with Galen's 'agnosticism' on the substance of soul. In this paper I propose a close reading of $Q A M$ that allows us to make sense of it in terms of Galen's other work, including his late work On My Own Opinions (De Propriis Placitis).
\end{abstract}

\section{Keywords}

Galen - soul - mixture

\section{Introduction}

In his late treatise entitled That the Capacities of the Soul Follow the Mixtures

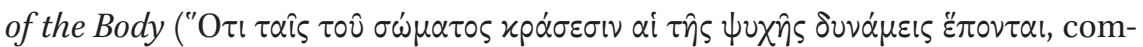
monly abbreviated after its Latin translation as $Q A M)$, Galen, besides arguing that psychic capacities 'follow' or 'depend' upon bodily mixtures, flirts - to say the least - with the thesis that the substance or nature of soul itself is nothing else than a specific bodily mixture. Thus, it has been noted that there are two separate theses advanced in $Q A M$ : (1) the weaker thesis described in its title, that the capacities of the soul follow the mixtures of the body; (2) the stronger thesis that we encounter in the first part of the treatise, that the substance of the soul is identical to a bodily mixture. As has been pointed out before, 
this stronger thesis provides us with some problems with regard to our understanding of Galen. Galen is well known for expressing his ignorance and lack of interest with regard to speculative questions, particularly the question of the substance of the soul. Why, then, would he advance such a strong reductionism or physicalism in $Q A M$ ? Notably, one of the works in which Galen repeatedly claims to not know the substance of the soul, is De Propriis Placitis (Prop. Plac.), a work which is dated after $Q A M$. Therefore, even if we were to make Galen's speculative wanderings in $Q A M$ itself intelligible, we are still stuck with another question: why, then, did he refrain from maintaining the stronger thesis in his later work?

Confronted with these questions, previous scholarship has come up with several strategic explanations for the presence of the stronger thesis in $Q A M$. The common assumption underlying these approaches seems to be that $Q A M$ 's bold reductionism cannot possibly be an expression of Galen's own thoughts, both because it conflicts with his other work as well as because it is considered simply too radical or extreme in itself. ${ }^{1}$ There has been quite a bit of scholarship on $Q A M$ already, but as I hope to show in this paper, its philosophical

1 Most recently, Peter Singer has ingeniously argued that Galen is not truly committed to the positions presented in $Q A M$, but rather presents the consequences of what he sees as an Aristotelian position, so that any 'more extreme statement' or 'apparent inconsistency', can be resolved by recognizing the hypothetical nature of the argument and conjecturing a 'conditional clause with the fundamental sense: "if Aristotle is right"' (Singer 2013, 335-73). This interpretation was previously advocated by the Spanish scholar Garcia-Ballester in an attempt to account for QAM's 'vagueness'. Garcia-Ballester also suggested that 'the involvement of socio-professional interests in motivating the formulation of such an extremely radical naturalism by Galen' (1988, 117-52, esp. 125-30). The latter approach has been worked out in more detail by Lloyd and Donini. Donini has proposed that as long as we interpret $Q A M$ as a 'more or less propagandizing manifesto devoted principally to promoting the image and the office of the doctor ... the threatened contradictions with respect to Galen's other works disappear' (2008, 200). According to Donini, 'Galen was fully conscious of the fact that in this treatise he was speaking at a different, indeed considerably lower, level than that of PHP' $(2008,201)$. Lloyd $(1988,42)$ states the same idea in a somewhat more careful manner: 'this would mean that his contributions to the debates on the relations between the soul and body, and to moral philosophical issues, are in places subordinated to a strategic concern with the prestige and power of the doctor'. I think that it is true that Aristotelian philosophy and terminology play an important role in $Q A M$, but I also think that a close reading of the text-as we shall undertake below-simply does not allow us to discard the thesis of the soul being a mixture as merely spelling out the supposed consequences of an Aristotelian position. Rather, as we shall see, this thesis can be understood as Aristotelian to the extent to which Galen's own position could be said to be Aristotelian. Naturally, the fact that Galen is a doctor and fervent advocate of the medical science has a strong and direct influence on his philosophical thinking and writing. However, to explain his supposedly 'extreme' or 'radical' views on the soul in terms of a kind of power-play between doctor and philosopher, is to radically reduce the richness and originality of the text, as well as Galen's self-understanding and his constructive relation towards philosophy, as I hope to show. 
import and relation to the rest of the Galenic corpus has not yet been adequately analysed.

What I offer in this paper is a reading that attempts to take $Q A M$ serious in its own right and that integrates its content with other Galenic works. Particularly, I will compare it with Prop. Plac. since, as one of Galen's latest works in which he again seems to be agnostic about the substance of soul, this is the most problematic case. Building on work of previous scholars, notably Mario Vegetti and Teun Tieleman, I aim to show that what Galen has to say on the soul in $Q A M$ —classed by Galen himself among the works 'on Platonic philosophy' (De Libris Propriis xix. 46 Kühn) — can be seen as a continuation of his earlier work and is not necessarily at odds with his repeated avowals of ignorance with regard to the substance of the soul. ${ }^{2}$ An important aspect of this reading is the epistemological status awarded to the stronger thesis and Galen's distinction between scientific knowledge and what is plausible $(\pi \mid \theta \alpha v o ́ s){ }^{3}$

Since our focus will be on the stronger of the two theses, I shall limit my analysis of $Q A M$ to the first part of the text. I shall argue that the two theses should be understood in their interrelationship, more specifically in that the stronger thesis is proposed by Galen as the best possible proof of the weaker thesis. Following the order of the text, we shall move from (1) Galen's introduction of the subject and delineation of his basic philosophical outlook on the soul involving tripartition, hylomorphism and the relation between the notions of capacity, activity and substance; (2) the discussion of the lower two parts of the soul in an exchange with Peripatetic philosophy; (3) the discussion of the (possibly immortal) rational part of the soul in an exchange with Platonism and the culmination of the argument in Galen's approval-with some adaptation - of the position of the Peripatetic Andronicus of Rhodes; (4) the comparison between QAM and Prop. Plac. and the distinction between knowledge and what is plausible.

Galen's Introduction of the Argument

Before Galen delves into the question of the substance of the soul, he makes some introductory remarks. He starts by stating that he has already found the weaker thesis to be true after repeated testing, both by himself and in the company of his teachers and 'the best philosophers'. Besides being true, he has also

2 Vegetti 200o; Tieleman 2003; also more recently Marechal 2019.

3 Cf. Frede 2003; Chiaradonna 2014; Tieleman 2018. 
found it to be useful, since good bodily mixture is conducive to becoming virtuous (QAM 32.9-13 Müller = iv. 768 Kühn):4

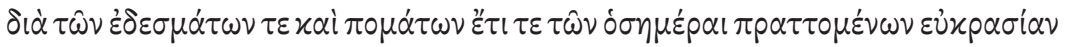

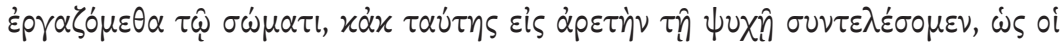

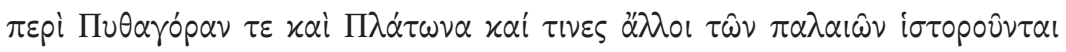
$\pi \rho \dot{\alpha} \xi \alpha \nu \tau \varepsilon \varsigma$.

We bring about good mixtures in the body through what we eat and drink, and also through our daily practices, and from this good mixture will achieve virtue for the soul — as the associates of Pythagoras and Plato are reported to have done, as well as certain others of the ancients.

Thus, at the beginning of the treatise, Galen attempts to stress the philosophical and ethical importance of what is to follow: when the soul is adequately understood in its dependence upon bodily mixture, it can be improved through adaptation of the mixture. Here we see that the theoretical point of what the substance of the soul is, a question Galen often shied away from answering, has crucial practical consequences that do concern him on a habitual basis.

In what follows, Galen takes up that theoretical question itself. First, he stresses what he designates as 'the starting point of the entire argument': the observable differences in actions and affections of small children. What does this mean and why is it so important to Galen's argument? He argues that these differences imply a difference in the capacities of the souls of these small children and that these differences in capacities imply a difference in the nature or substance of their souls (Galen states that it is evident that the words ov $\sigma i \alpha$ and

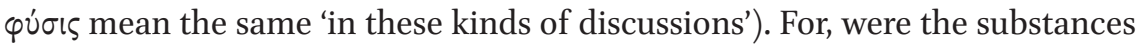
of their souls the same, their affections and actions would be the same too. From this we can infer that, whatever the substance of soul will turn out to be in the subsequent discussion, it will have to account for these differences in small children, since that forms, as Galen says, the empirical basis of the entire argument.

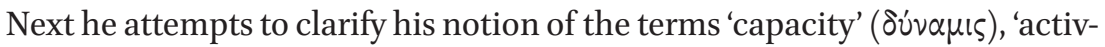

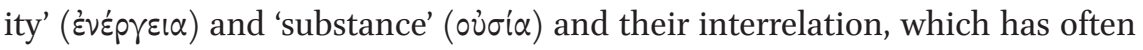
been misunderstood by 'many of the philosophers' (and we shall see later that this is exactly the point where Galen disagrees with Andronicus). The misunderstanding revolves around their notion of 'capacity'. According to Galen, they conceive of a capacity as being some kind of 'thing' that inhabits the

4 Translations of $Q A M$ are from Singer 2013, sometimes with modification. 


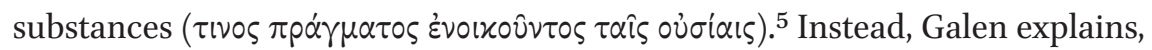
a capacity is nothing but a name given in relation to a certain activity. The agent of those activities, the cause, is the substance itself, as his example of aloe makes clear; and in retrospect the substance could thus be said to 'have' the capacity for doing what it does. But this does not mean, then, that there is something else required besides the substance itself to give a causal explanation of what takes place (QAM 34.1-10 Müller = iv. 769-70 Kühn): 6

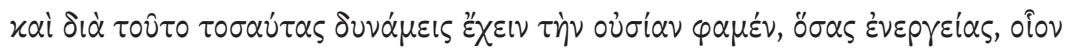

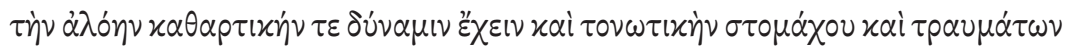

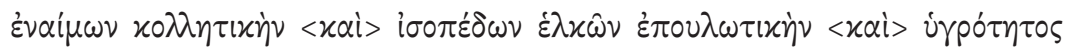

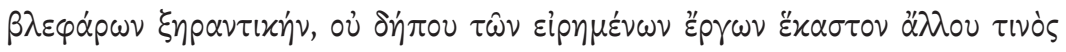

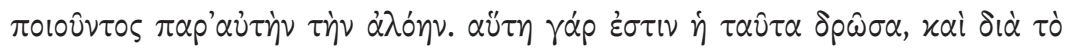

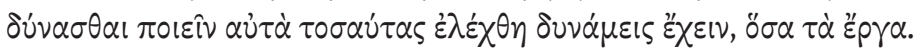

And therefore we say that the substance has as many capacities as activities; for example that aloe has a capacity for cleansing and toning the mouth of the stomach, of agglutinating bleeding wounds, of cicatrizing grazes, and of drying the wetness of the eyelids-without there being some other thing that performs each of these actions apart from the aloe itself. For it is the aloe that does these things; and it is because it can do these things that it is said of it that it has these 'capacities', as many as the actions.

As Jim Hankinson has put it, the notion of capacity for Galen is a kind of 'place-holder for a proper, full-blooded causal explanation, a useful form of words to be employed when such an explanation is not yet available, but by

5 QAM 33.17-28 Müller = iv. 769 Kühn.

6 Cf. Nat. Fac. 1.4, ii. 9-10 Kühn: 'But, if the cause is relative to something-for it is the cause of what results from it, and of nothing else-it is obvious that the capacity also falls into the category of the relative; and so long as we are ignorant of the substance [ $\tau \dot{\eta} \nu$ ov $\sigma i \alpha \nu]$ of the cause

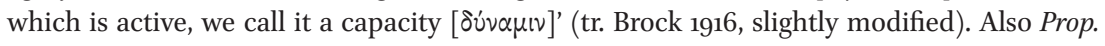

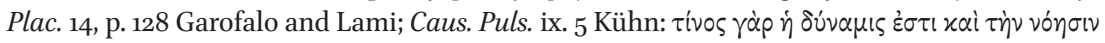

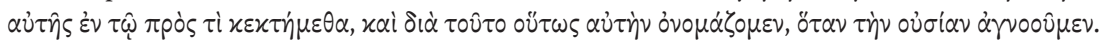
See also Frede 2003, 94 with reference to Prop. Plac. 14: 'We know that there is a soul, because the soul makes us do the things we as living beings do, like walk or run. But we do not know what it is, and hence also do not know what it does such that as a result of it we walk and run and do all the other things living beings do. Hence we introduce powers named after the observable effects of its activity, of its exercise of its power, for instance the natural powers'. 
no means a substitute for it. ${ }^{7}$ Building on the example of the aloe, Galen states that we could say the same thing about the rational soul 'that is seated in the brain'. That is to say, there is a substance that is doing things such as perceiving and understanding, which we do not know yet but which we have to infer on the basis of the activities that are manifest, and therefore we say that this substance has the capacity for doing these things.

I have put some emphasis on this point, because once we recognize that in Galen's view it is the substance that is primarily active and that does things, and that we attribute 'capacities' to this substance on the basis of its activity, it becomes evident that proving that the substance of the soul is a bodily mixture is more than conducive to proving the thesis that the capacities of the soul are dependent on the mixture of the body. That is to say: Galen establishes here that capacities are per se dependent upon substance since they are what we predicate of substance on the basis of its activities as long as we do not know the actual substance itself, implying that if we do get to know the substance and show the substance of the soul to be a bodily mixture, that is the best proof we can get that the capacities of soul are dependent upon bodily mixture. Thus, this is how the two theses are related: proof for the stronger thesis that states that the substance of the soul is a bodily mixture is the most reliable proof for the weaker thesis that the capacities of soul follow or are dependent upon the mixture of the body.

Next is the introduction of the familiar tripartition and trilocation of soul and the status aparte of its rational part. Galen first remarks that he cannot decide on the question of the immortality of the rational soul, so that he will postpone the discussion of this part and first discuss the souls located in heart and liver, which he does through an exchange with Aristotelian philosophy.

Now, Galen states that each of these organs has its own specific substance ('i $\delta \alpha \circ \dot{0} \sigma i \alpha)$ and that it has been previously shown by him that the common

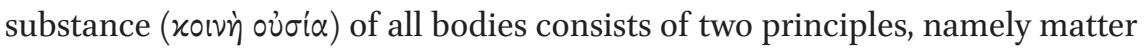
and form, matter being without quality and form being a mixture of the four qualities hotness, coldness, dryness and wetness. This is obviously Peripatetic to some extent at least, but that does not mean it is not also Galenic. That is to say, Galen clearly presents this as his own position, as we can corroborate

7 Hankinson 2003, 51; see also Hankinson 2006, 242 ff. and 2014, 964ff;; Tieleman 2003, 144-51; Chiaradonna unpublished. 
throughout the rest of his work. ${ }^{8}$ Notice also that now we have made a few leaps from the original question about the substance (or nature) of soul: in introducing the tripartition and trilocation, the discussion has shifted to the substances of the organs, which are then furthermore included in a doctrine on the hylomorphic substance of all bodies. As we shall see, Galen simply assumes the Aristotelian definition of soul as form of the body. The simplest bodies, that are often called 'perceptible bodies' or also 'perceptible elements' by Galen, are the homoeomerous bodies, which we cannot analyze further except conceptually in terms of their form (mixture of four elemental qualities) and matter (without qualities). In this particular passage, Galen gives the examples of bronze, iron and gold, but also of flesh, sinew, gristle and fat. More complex bodies, among which are the organs, are called anhomoeomerous and are constructed out of a number of homoeomerous bodies. ${ }^{9}$ So now the question becomes: given that soul is located in these three different organs that are made out of homoeomerous bodies that consist of form and matter, what should be identified as the cause of its respective activities? For, given the assumption that soul is form of the body, there are now two options open for Galen, corresponding to the two respective levels of composition of the organ in which the soul resides: is the cause of our activities to be found in the homoeomerous bodies that constitute the organ, or is it rather to be found in the organ as such? Here Galen's answer is clear and this is a point where his view seems to depart from most of the Peripatetic tradition (though maybe not all) and certainly from Aristotle (QAM 37.5-15 Müller = iv. 773-4 Kühn):

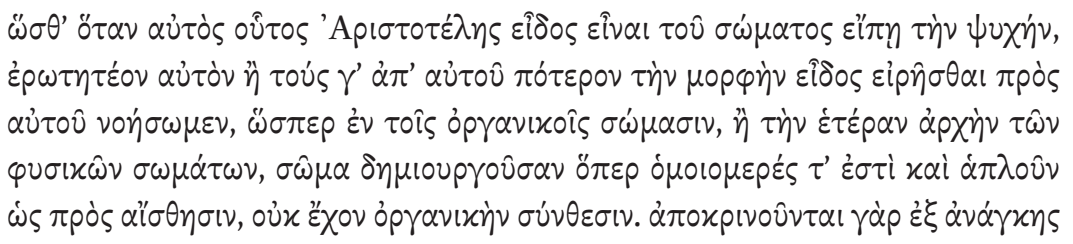

8 Hipp. Elem. 114.16ff. and 126.1ff. De Lacy; Nat. Hom. 17.28-18.15 Mewaldt (= xv. 30-1 Kühn); Prop. Plac. 7.2, p. 86 Garofalo and Lami (cited below); Hankinson 2008, 210-36 and 2017; Kupreeva 2014, with an interesting comparison to Boethus (ap. Simplicius, In Cat. 78.10-20 Kalbfleisch) that suggests that perhaps there were Peripatetic precedents for Galen's particular view (see also Chiaradonna unpublished on this). There is of course also a Stoic tradition of dualism in which one of the principles is a prime matter without quality and the other is the active principle (cf. Sedley 2011): there are obviously differences between that account and Galen's, but there are also resemblances. Interestingly, as Sedley has shown, the Stoics strongly based this dualism on Plato's Timaeus, which happens to have been one of Galen's favourite philosophical works as well.

9 For this distinction, which Galen takes from Aristotle (e.g. PA 2.1, 646a12-24): Nat. Hom. 6, 11 ff. Mewaldt (= xv. 7-8 Kühn); PHP 8.4, 500.3 ff. De Lacy; Part. Hom. Diff., including Strohmaier 1970, 87-94. 


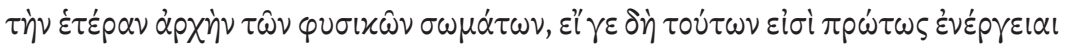

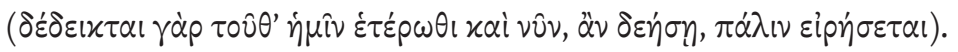

Therefore when this Aristotle himself says that the soul is form of the body, one must ask him, or his followers, whether we should understand form here to have been used by him in the sense of shape, as in the organic bodies, or in the sense of the other principle of natural bodies, that which crafts a body that is homoeomerous and simple in terms of perception, not having organic composition. For they have to answer, necessarily, that it is the other principle of the natural bodies-since, indeed, to these the activities primarily belong (this has been shown by us elsewhere, and will be stated again now, if you require).

Assuming these two different principles, operating at different levels of our bodily constitution, Galen identifies the principle that crafts homoeomerous bodies as the proper location of the substance of soul, since the activities belong there primarily. This choice is also in line with Galen's general assumptions about what constitutes the nature or substance of a being, as we find throughout his work, for example in the opening passage of De Elementis ex Hippocrate, where he states that 'if we are to obtain precise knowledge of the nature of man or any other being' we need to determine which parts of it are first and simplest and cannot be further divided..$^{10}$ Likewise, in In Hippocratis De Natura Hominis, we find Galen repeatedly citing a passage from Plato's Phaedrus, in which he sees the same methodological approach (Nat. Hom. 5 . 1-6 Mewaldt $=$ xv. 5 Kühn, tr. modified from Hankinson, forthcoming :

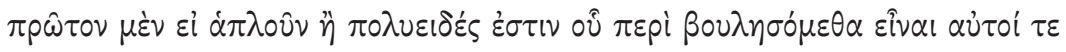

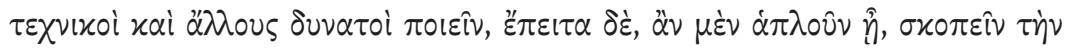

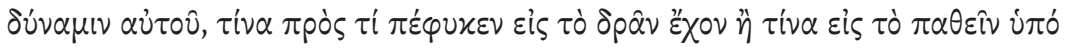

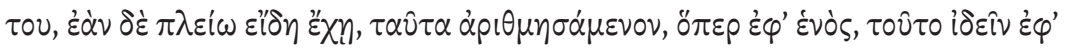

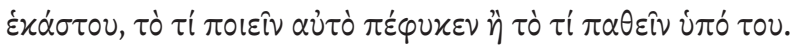

Concerning anything in which we both want to be technically proficient ourselves and to be able to make others so too, we must first determine whether it is simple or complex, and then, if it turns out to be simple, to examine what power it has by nature for acting, and in respect of what, and what < power $>$ it has for being affected by something; while if it has

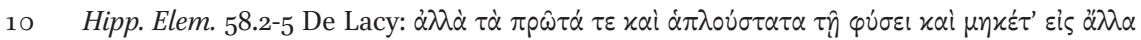

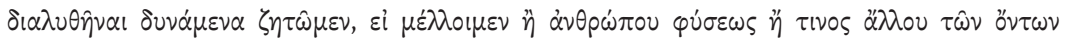
$\dot{\varepsilon} \pi เ \sigma \dot{\eta} \mu \eta \nu \dot{\alpha} x \rho ı \beta \hat{\eta} \lambda \dot{\eta} \psi \varepsilon \sigma \theta \alpha \iota$. 
many forms, we must enumerate them, and then do for each of them what we did in the case of the single one, namely what it by nature does to what, and how it is acted upon and by what.

Galen obviously likes this passage a great deal, for several reasons. First of all, in the immediately preceding context, Hippocrates is credited with having described this as the proper method for investigating nature, and it is implied that the inquiry into soul needs to build on this. In De Methodo Medendi 1.2, Galen summarizes this point as follows: 'Plato thinks it proper to use in the investigation of the soul the same method as that employed by Hippocrates in the case of the body' (x. 13-4 Kühn, tr. modified from Hankinson 1991). Again, towards the end of the first book of Nat. Hom., he returns to the quotation from the Phaedrus and says that we can now conclude that Hippocrates did follow this method and that Plato agreed that one must apply this method also for inquiring into soul. ${ }^{11}$ Here, we must remember that Galen classified $Q A M$, where he discusses the question of the nature or substance of the soul, as a work 'on Platonic philosophy'. That is to say, it is not unreasonable to think that he is applying this very same method to the nature of the soul, departing from the notion that the soul is form of the body and concluding that soul must then be a mixture of the most elemental qualities, because these are the primary powers of the smallest constituent parts of the organs liver, heart and brain.

Now, if we return to $Q A M$, this is in fact what Galen does next (QAM 37.16-21 Müller = iv. 774 Kühn): ${ }^{12}$

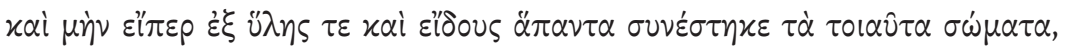

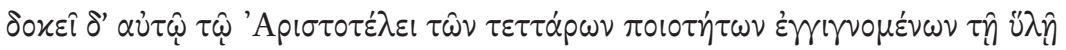

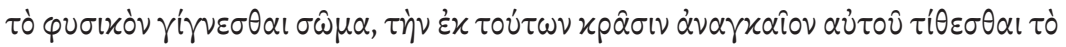

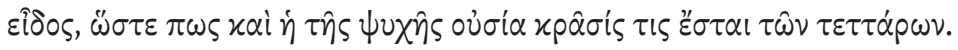

$11 \quad$ Nat. Hom. xv. 53.15-54.12 Mewaldt = xv. 102-3 Kühn.

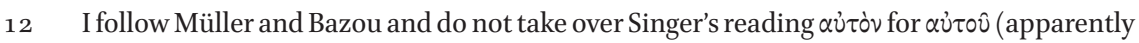
supported by the Arabic, but not in the Greek MS tradition), which would give 'it is necessary for him' (i.e. Aristotle), and eliminate the 'of it' (referring to the matter) after 'form'. Cf. Singer 2013 ad loc. (Singer's reading supports his interpretation of Galen's argument being hypothetical, spelling out the consequences of an Aristotelian position.) Singer also remarks in a note to his translation $(2013,381 \mathrm{n} .38)$ that 'the adverb [ $\pi \omega \varsigma]$ suggests that this is a surprising conclusion which is nonetheless drawn'. He translates $\pi \omega \varsigma$ as 'it seems as if' ('so that it seems as if the substance of the soul, too, will be some mixture of the four ...'). In my view, $\pi \omega \varsigma$ can be translated simply as 'somehow', referring to the immediately following remark, that this 'mixture of the four' can be understood in several ways $\left(\varepsilon \iota^{\prime} \tau \varepsilon \ldots\right.$... $\left.\varepsilon^{\prime} \tau \varepsilon \ldots\right)$, namely as a mixture of qualities $(\pi 010 \tau \dot{\eta} \tau \omega \nu)$ or bodies $(\sigma \omega \mu \dot{\alpha} \tau \omega \nu)$. Cf. Moraux's translation $(1984,780)$. 
And surely if all such bodies are composed of matter and form, but according to Aristotle himself the natural body comes to be because the four qualities come to be in the matter, it is necessary to posit the mixture of these as the form of it, so that the substance of the soul too will somehow be some mixture of the four.

Now, it is important to note that this view, that the four elemental qualities constitute the substance of a thing and are the primary cause of its activities, is not something we only find in $Q A M$, which might be considered philosophically more speculative, but rather something we find throughout Galen's work. Just to give an example (Hipp. Elem. 132.9-13 De Lacy = i. 485 Kühn, tr. DeLacy):

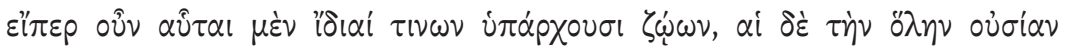

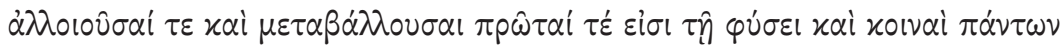

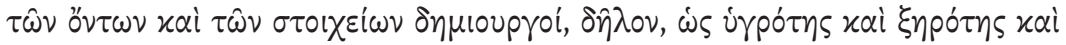

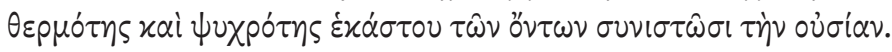

If then these (qualities) are peculiar to some animals, but those that alter and transform the whole substance are primary in nature and common to all existing things and are artisans of the elements, it is clear that wet, dry, hot and cold form the substance of each thing that exists.

The elementary qualities make up the substance of each individual thing. ${ }^{13}$ Galen referred to this substance in the passage from $Q A M$ we cited earlier, saying that each of the organs in which the soul resides has its own particular sub-

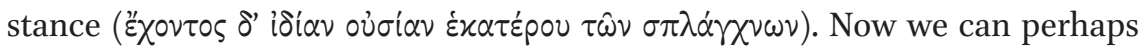
start to think of a different way in which the soul is seated 'in' the organs. That is to say, in the sense that there are substances in the organ, that are cause of the activities which we qualify as psychic.

From these observations we can gather that the preliminary conclusion developed in $Q A M$ in interaction with Peripatetic philosophy—-that the substance of soul must be a specific mixture of elemental qualities in the organs in which soul resides-is consistent with (I would almost say 'follows from') (1) Galen's general methodology for establishing the nature or substance of things and (2) his view on the primary role of the elementary qualities with regard to determining substance and activity.

13 See also Hipp. Elem. 138.15-17 De Lacy (= i. 492 Kühn); Nat. Fac. ii. 134 Kühn; Nat. Hom. 17.18 ff. Mewaldt (= xv. 29-30 Kühn), 22.4-8 Mewaldt (38 Kühn), 28.10-14 Mewaldt (51 Kühn). 
We return to $Q A M$. After the conclusion that the substance of the souls seated in heart and liver must be mixtures of the elemental qualities, Galen is now ready to move on to the previously postponed subject of the rational part of the soul ( QAM 37.1-38,8 Müller = iv. 774-5 Kühn):14

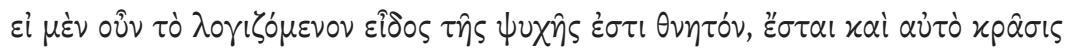

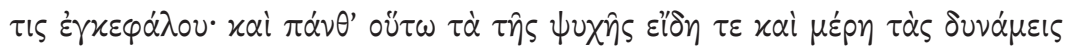

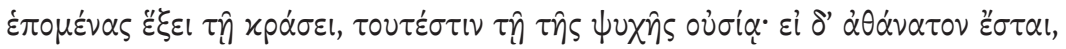

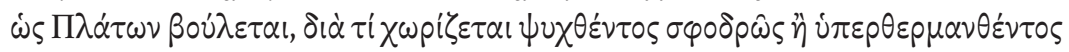

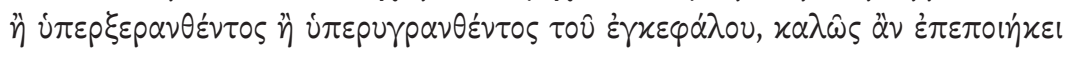

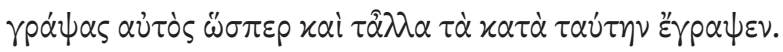

Thus if the reasoning form of the soul is mortal, it too will be a particular mixture, [namely] of the brain; and then all the forms and parts of the soul will have their capacities dependent on the mixture - that is, on the substance of the soul; but if it turns out to be immortal, as Plato would have it, he would have done well, himself, to write an explanation as to why it is separated when the brain is excessively cooled, heated, dried or moistened, as he wrote about the other matters concerning it.

Galen adds that we unfortunately cannot question Plato himself about this issue, given that he is no longer around (I think one can gather Galen's position from this joking remark alone). At this point, the interaction with Aristotelian philosophy is concluded, but what remains is the conclusion that the substances of the two souls that are certainly considered mortal by Galen, are mixtures. Now, for the first time, it is suggested that the same conclusion might be applied to the rational part of the soul as well. It is important to note that Galen presents the discussion for the rational part in the form of a disjunction: if it is mortal, it is a mixture as well; if it is immortal, we would need a different explanation, since for Galen that implies that it 'has a nature of its own', i.e. some nature that is separable from the body. ${ }^{15}$ Obviously, the rational

14 Here I follow Bazou's text, except for her addition of $\alpha \tilde{u} \tau \eta$ after $\delta i \dot{\alpha} \tau i \chi \chi \omega \rho i \zeta \varepsilon \tau \alpha l$ (which I agree with Singer seems unnecessary) and in line 8 reading है $\sigma \tau \alpha$ in accordance with

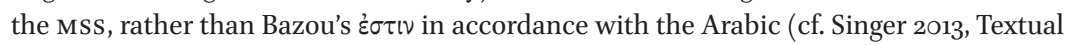
Notes 4.13-15).

15 QAM 48.5-6 Müller (= iv. 787 Kühn) but following Singer (2013, Textual Note 4.27) not

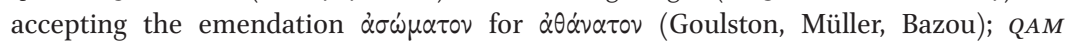
46.17-23 Müller (= iv. 785 Kühn). 
soul has to be either mortal or immortal: there is no further option. In what immediately follows, Galen proceeds to argue against one side of the disjunction, namely that the rational soul is immortal or that it has a separate existence of some kind, mostly by showing how the observational evidence speaks against it. ${ }^{16}$ Hence, given the overall structure of his discussion, these arguments can be taken as supporting the other option, viz. that the rational soul is mortal, from which it follows, according to Galen, that the rational soul is a mixture as well, that is, as the other two souls have been shown to be. ${ }^{17}$ Also, we can clearly see the relation between the two theses of QAM in this passage: if it is shown that the rational form is mortal and thus a mixture, it has been proven that the capacities of all three souls are dependent upon a bodily mixture.

This view, that all three parts of soul are mixtures, presented here in hypothetical form, is the same as the view that Galen approvingly ascribes to Andronicus a bit further in the text, right after he has argued against the immortality and incorporeal existence of (the rational part of) the soul. The structure of the text, surprisingly ignored in most scholarship, is telling in that regard.

Let us now first have a look at the way Galen presents Andronicus' position, after the arguments against the immortality of the soul (QAM 44.12-45.3 Müller = iv. $782-3$ Kühn): ${ }^{18}$

16 This might seem surprising, given that Galen considers $Q A M$ a work 'on Platonic philosophy', as we have mentioned, but it does fit with Galen's general interpretation of Plato, particularly of the Timaeus, of which he seemed to have advocated a reading in which the opposition between body and (rational) soul is to some extent recast into an opposition of different elemental qualities. Although the immortality or separate existence of the soul may appear as one of the most fundamental Platonic doctrines, Galen has an elaborate interaction with the Timaeus without accepting this doctrine. This comes to the fore in his so-called Compendium of the Timaeus (which is an interpretative work at least as much as it is a mere summary), in the fragments of his Timaeus commentary collected in Daremberg 1848 and later re-published in Schröder and Kahle 1934, a few other scattered places in the Galenic corpus, and finally also in the excerpts collected by Larrain, of which the authenticity is at least doubtful, but which might have been based on Galen's actual commentary on the Timaeus. This topic cannot be further pursued in the present paper, but will be treated more extensively in my forthcoming dissertation.

17 Clearly, the rational soul does have an exceptional position in Galen's discussion, particularly because it has the capacity to transform the bodily mixture to some extent, but there is no space to pursue this further here either. When Neoplatonist authors such as Proclus, John Philoponus and Olympiodorus refer to $Q A M$, however, the main thesis is generally accepted as long as the rational part is exempted: see Proclus, In Remp. i. 222 Kroll; Olympiodorus, Commentary on Plato's Gorgias 49.6 Westerink (ad 524d5-6); Philoponus, On Aristotle's On the Soul 50.32 ff. Hayduck (and the notes as loc. in van der Eijk 2006).

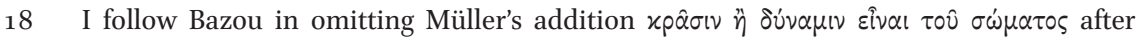

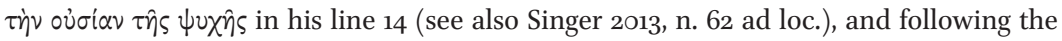




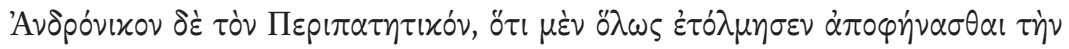

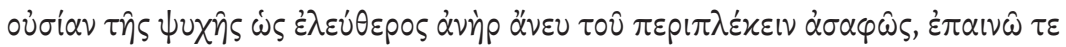

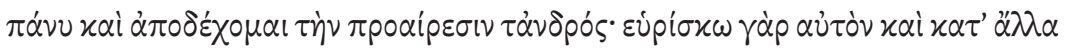

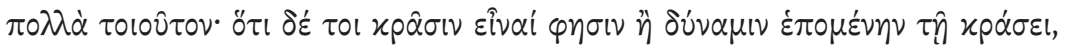

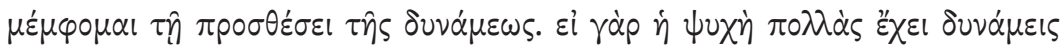

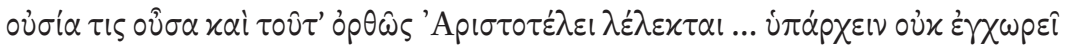

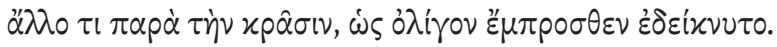

And as for Andronicus the Peripatetic, because he dared to speak out on the substance of the soul as a whole, in the manner of a free man without beating around the bush, I praise him highly and I accept the position of the man (and I find him similar in many other areas, too). But surely when he says that it is a mixture or a capacity dependent on the mixture, I disapprove of the addition of capacity. For if the soul has many capacities, while itself being some kind of substance, and this has been said correctly by Aristotle ... it is not possible for it to be anything else but the mixture, as has been demonstrated a little before.

First of all, it is notable that Galen here emphasizes Andronicus' audacity. Apparently, he considers it daring to argue freely for the substance of the soul being a mixture. Why would that be? In fact, this is a recurring motif in Galen. A few pages earlier, when arguing against the possibility that the soul is immortal, Galen said that he 'dares' to state — against Plato — that not every kind of body is suitable to receive the rational soul (which implies that the rational soul is dependent upon a specific bodily constitution, which implies that it does not have a nature separate from the body, which implies that it is mortal) $(Q A M$ 38.16-23 Müller = iv. 775-6 Kühn):

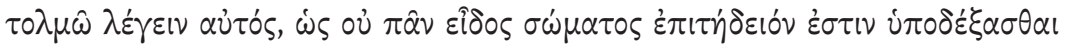

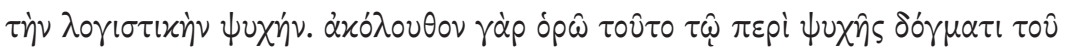

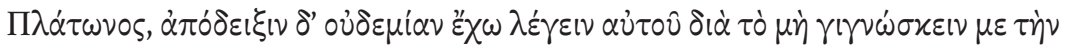

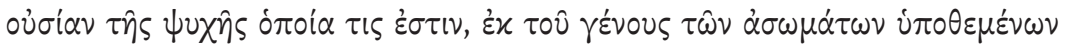

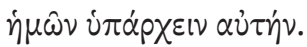

I dare to state myself, that not every kind of body is suitable to receive the rational soul. For I see this as consequent upon Plato's doctrine of the soul, but I am not able to state any demonstration for it, because I

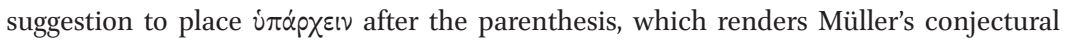
$\lambda \varepsilon ́ \gamma \varepsilon\llcorner\nu$ (followed by Bazou) unnecessary. Cf. Singer 2013, Textual Note 4.21. 
wouldn't know what kind of thing the substance of the soul is, if we take as our assumption that it belongs to the class of non-bodily things.

Furthermore, there is a remarkable passage in his Prognosis by the Pulse (Praes. Puls.), as Matyás Havrda has noted, ${ }^{19}$ where Galen says that he previously did not dare to assert anything about the substance of the capacity of pulse, but that now he does (2.8, ix. 305.16-306.4 Kühn, tr. after Havrda 2017, 77):

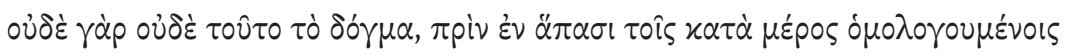

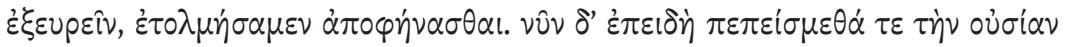

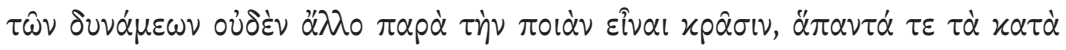

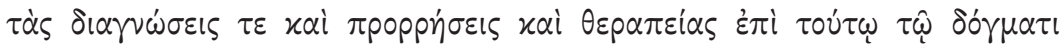

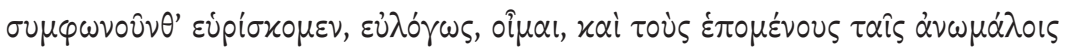

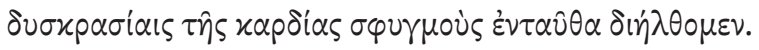

This is because I did not dare to assert this belief, before finding out if all particular [observations] are in agreement with it. But now, since we have already been convinced that the substance of capacities is nothing but a particular mixture and, since we have found that all [observations] regarding diagnosis, prognosis and therapy are in agreement with this view, it was reasonable, I suppose, that we would also give an account on this occasion of pulses that follow the anomalous imbalances of mixture in the heart.

Interestingly, Galen here states the reason for his previous carefulness: first it had to be established that all observations are in agreement with it. Here we may recall that in $Q A M$ Galen placed great emphasis on the observable differences between small children as the starting point of his argument and we may also think of the observational evidence that he presents as being at odds with the Platonic notion of an immortal soul. In yet another work, De Symptomatum Causis, Galen states that he might have the audacity to make a statement with regard to the substance of the soul elsewhere. ${ }^{20}$ Now in $Q A M$, we find Galen applauding Andronicus for making such a statement and expressing his approval of it, except for the fact that Andronicus said — according to Galenthat the substance of the soul could also be a capacity dependent on the mix-

19 Havrda 2017, 77; cf. also Ut. Resp. iv. 472 Kühn.

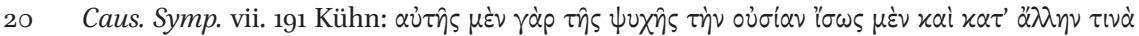
$\pi \rho \alpha \gamma \mu \alpha \tau \varepsilon i \alpha \nu \alpha \dot{\alpha} \pi \circ \varphi \eta^{\prime} \alpha \alpha \sigma \theta \alpha \mathrm{l} \tau 0 \lambda \mu \eta \rho \dot{\nu} v$; cf. also Frede 2003, 79 on UP: 'There clearly is some suggestion of the inscrutability of nature's or the Demiurge's ways, of the impropriety of daring ( $\tau 0 \lambda \mu \hat{\alpha} \nu$, II p. 342,6 and 8) to inquire into things which it is not for human beings to know.' 
ture. This is clearly at odds with Galen's previous definitions of capacity and substance, as we have seen. Therefore, he clarifies that a substance could be said to have capacities, but not to be itself a capacity, and that therefore the substance of the soul can only be a mixture, as he now takes himself to have demonstrated already. ${ }^{21}$

At this point, however, we are not even halfway through $Q A M$ : Galen still proceeds to give many examples, basing himself on Aristotle, Hippocrates and Plato, that aim to show that the bodily mixture in one way or another determines the state or activity of soul. That is to say, he proceeds to argue for the weaker thesis of QAM described in its title. There is a clear demarcation in the text, where Galen moves from arguing for the stronger thesis to the weaker one, in which he says the following $(Q A M$ 48.3-8 Müller = iv. 787 Kühn $): 22$

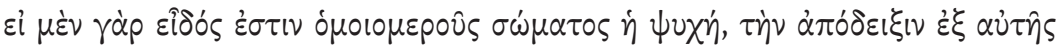

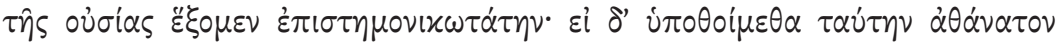

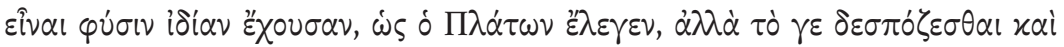

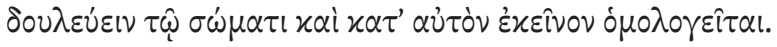

For if, on the one hand, the soul is a form of a homoeomerous body, we shall have the demonstration based on its very substance, which is the most scientific demonstration possible. If, on the other hand, we would

21 Interestingly, according to Themistius, Andronicus held that the soul is cause of the mixture, as a tuning that attunes itself. This seems to be at odds with the way Galen presents his view. However, we could perhaps align Galen's depiction of Andronicus with that found in Themistius, if we take Galen's distinction between substance and capacity here to refer to a specific kind of mixture and its capacity to be a cause of movement, so that Andronicus' position would be that soul is the tuning that causes the specific mixture to which the capacity for self-movement belongs, which would then cause confusion over which properly should be called soul: the tuning or the resulting capacity for self-movement. Galen would then disagree with the addition of capacity, because in $Q A M$ he rather suggests that the cause of movement is the mixture itself, that is to say, it as a specific bodily mixture. See Themistius' commentary on De Anima at 32.26-31

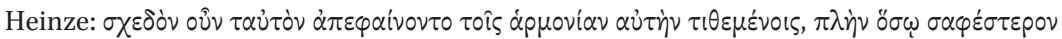

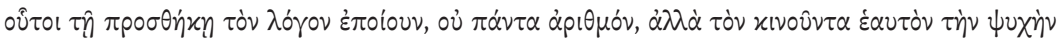

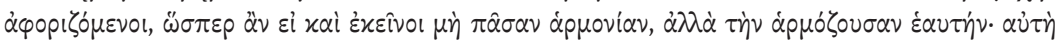

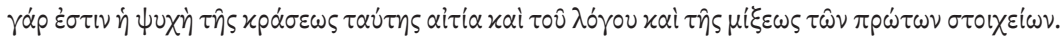
(I thank Jaap Mansfeld for pointing out this passage.) Cf. Moraux 1973, 45-143, esp. 132-4; Chiaradonna unpublished.

22 Following Singer, I stay with the Mss tradition here, reading $\dot{\alpha} \theta \dot{\alpha} v \alpha \tau o v$ and not accept-

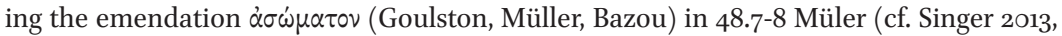
Textual Note 4.27) — but for a different reason: Galen here returns to the earlier disjunction between the soul being mortal (and thus a mixture) or immortal. This also means that the difference between $\dot{\theta} \theta \dot{\alpha} v \alpha \tau o v$ and $\dot{\alpha} \sigma \dot{\omega} \mu \alpha \tau o v$ is not as important as it might seem here, since they necessarily go together for Galen in this argument. 
take it to be something immortal, having a nature of itself, as Plato said, even then he himself agrees that it is dominated by and enslaved to the body.

The 'demonstration' here refers to the demonstration of the central thesis of QAM, as the preceding sentences make clear. The most scientific demonstration of this thesis is that proceeding from the substance of the soul, namely the demonstration that shows that the substance of the soul must be the form of a homoeomerous body, that is to say, the mixture of elemental qualities. Again, such a demonstration would logically imply that the capacities of the soul are dependent on the mixtures, since capacities are dependent on the substance of which they are said to be capacities. But, states Galen, even if we would take the soul to be something immortal, which would mean that the central thesis of $Q A M$ would not be directly proven from the substance of the soul itself, then we could still prove the central thesis, even by means of what Plato himself has said. Hence, in the remaining part of $Q A M$ Galen proceeds to take up the other side of the disjunction he set out when starting the section about the rational soul, although it has already been repudiated, and shows how even if the immortality and separate nature of soul would be accepted, QAM's weaker thesis still remains true.

That, however, is not what concerns us here. What remains now, is to refine our analysis of the argument for the strong thesis in $Q A M$ by comparison with Prop. Plac., one of Galen's latest works in which he again expresses his 'agnosticism' with regard to the substance of the soul.

\section{Prop. Plac. and the Distinction between Knowledge and What is Plausible}

In Prop. Plac., Galen explicitly claims several times that he does not know what the substance of the soul is. ${ }^{23}$ Unfortunately, he does not refer to $Q A M$ at all, which is remarkable in itself. In this regard, it is important to note the explicit strategic aim of Prop. Plac: Galen, finding himself in a similar situation as the poet Parthenios, as he states, is defending himself against wrong interpretations of his works. He presents this predicament as the very reason for writing the work.

More specifically, Galen remarks that people have often misunderstood the status of some of the things he wrote. Thus, there has apparently been a

23 Prop. Plac. 3.1, p. 64 Garofalo and Lami [173.16-18 Boudon-Pietrobelli]; 7.1, p. 86 [179.28-9]; 15.1, pp. 136-8 [188 27-30]. 
mix-up of things he has claimed to know and things he has merely claimed

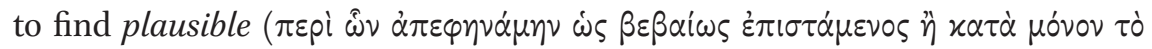
$\pi(\theta \alpha v o ́ s)$; presumably, considering the apologetic and careful tone of the whole text, others have taken some views that Galen has presented as plausible as if they were presented by him as having the status of scientific knowledge.

Now, if we look at what he has to say on the substance of the soul in particular, we notice that, despite the fact that $Q A M$ is not explicitly referred to, the views that are elaborated there certainly do surface here as well. In Prop. Plac. 7.2 , we find something quite reminiscent of what we read in $Q A M$, interestingly right after Galen again remarked that he does not know what the substance of the soul is (p. 86 Garofalo and Lami $=178.29 f f$. Boudon-Pietrobelli):

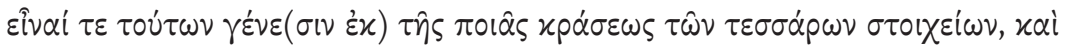

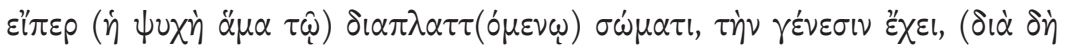

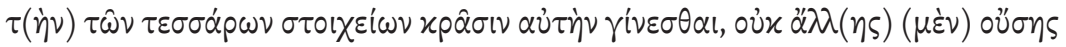

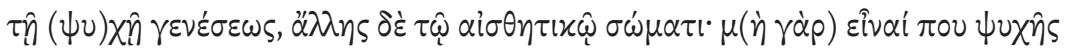

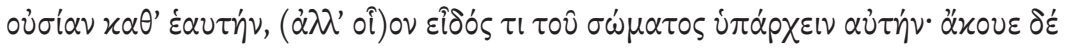

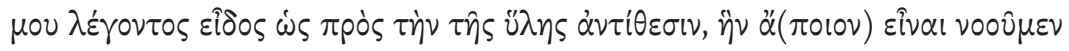

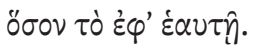

And that the generation of them [the organs of perception] is from the specific mixture of the four elements, and if the soul has its generation together with the formation of the body, then it itself comes to be because of the mixture of the four elements, since there is not one generation of the soul, and another of the sense-perceiving body; and I suppose that there is not a substance of the soul existing by itself, but that it is a kind of form of the body; understand when I say form I mean the opposite of matter, which we understand to be without quality taken in itself.

Here, pretty much immediately after saying that he does not know the substance of the soul, Galen proceeds to suggest that the soul comes to be from the mixture of elements, that the soul does not have a generation separate from that of the body, that there is no separate substance of the soul (remember here the disjunction from $Q A M$ ) and that the substance of the soul is rather a kind of form of the body. These are exactly the same views as those he expounds in $Q A M$. How is it possible, then, that Galen can say all this about the substance of the soul - that it is the form of the body, and that form is to be understood as a mixture of the four elemental qualities, since it is the form of the most basic matter-while at the same time proclaiming that he does not know what the substance of the soul is? The answer to this question is really 
quite simple, I think, and lies in the difference he made at the outset of Prop. Plac., between what he thinks he knows and what he thinks is plausible. The

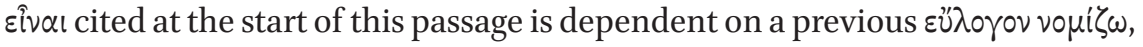
'I consider it reasonable', and as we have seen Galen also adds an extra $\pi \circ v$, 'I think / suppose', when he gives his take on the actual substance of the soul. By contrast, at the start of Prop. Plac. 7, and again after the passage cited above, where he denied knowledge of the substance of the soul, he expresses him-

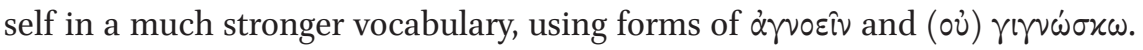
Hence, in this late work that seems 'as much an apology as a career conspectus', as Aileen Das has aptly put it, ${ }^{24}$ Galen states that although he does not know what the substance of the soul is, he does consider the notion that it is a mixture of elemental qualities reasonable or likely. It seems as if he regards this view as belonging to the class of plausible ones, having some persuasiveness about it. I think that, in this case at least, that means that he distinguishes it not only from views that have scientific status, but also from views that qualify neither as knowledge nor even as plausible. In this regard, it is important to realize that Galen does not only contrast what is plausible $(\pi \theta a v o ́ s)$ with what is certainly true, but also with what is completely unlikely $\left(\dot{\alpha} \tau 0 \pi^{i} \alpha\right) .{ }^{25}$

Further on in Prop. Plac., we find another passage reminiscent of $Q A M$, particularly of the passage on the relation between substance, activities and capacities (14.1, p. 128 Garofalo and Lami = 187.14-22 Boudon-Pietrobelli):

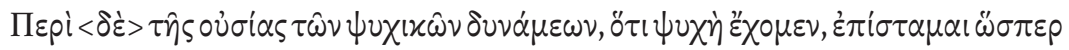

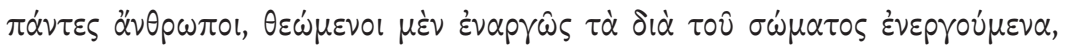

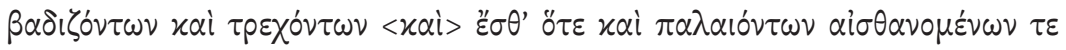

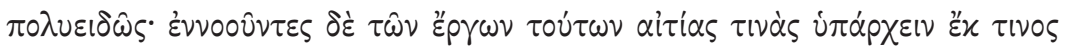

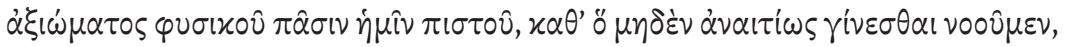

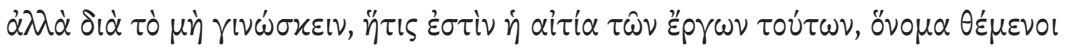

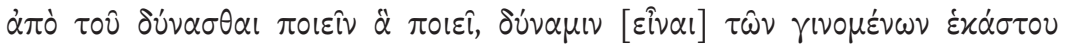
$\pi 0 i \eta \tau \leftarrow \dot{\eta} v$.

With regard to the substance of the psychic capacities, that we have a soul, I know as all men do, because we clearly see the activities performed by the body, walking and running and sometimes also wrestling, and senseperception of many kinds, and because we understand that there are certain causes of these actions, on the basis of a natural axioma trusted

24 Das 2014, 2.

25 An example is Hipp. Elem. 86.14 De Lacy (= i. 442 Kühn); but on Galen's use of $\pi$ ı $\theta$ vós, see Chiaradonna 2014 and Tieleman 2018. 
by all of us, according to which we consider nothing to happen without cause; but because we do not know what the cause of these actions is, we postulate a name based on the [subject] being able to do the things that it does, a capacity as the efficient cause of each of the things that happen.

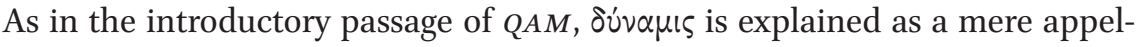
lation ( ${ }^{\prime} v o \mu \alpha$ ), because the true efficient cause of the activities, the substance (ov $\sigma^{i} \alpha$ ), is unknown. The fact that the activities are there prove that soul exists as their cause (just as, for Galen, the existence of well-designed creatures proves that an intelligent creator exists), but because we do not know what soul itself is, we name the causes of the activities in terms of capacities, while it is really the substance that is the cause. ${ }^{26}$ As in $Q A M$, where it was aloe, Galen gives examples of the capacities of substances used for medical purposes, scammony and medlar in this case.

Now Galen proceeds to enumerate two basic positions with regard to what the soul is: there are those that state that incorporeal capacities 'inhabit'

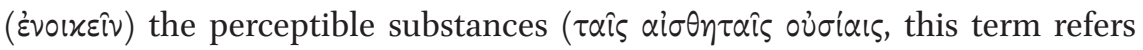
to the homoeomerous bodies), and those of the opinion that the substances

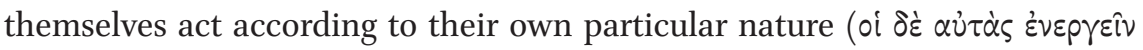

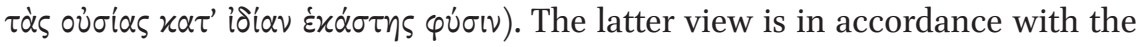
notion that the substances themselves are the true efficient causes of activities, presented just a little earlier and argued for in QAM (Prop. Plac. 14.3, p. 132 Garofalo and Lami = 188.1-6 Boudon-Pietrobelli):

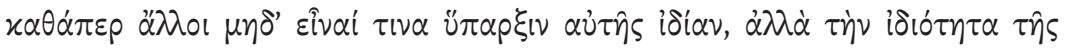

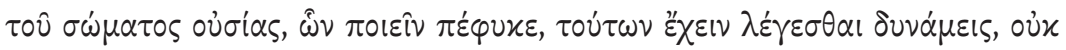

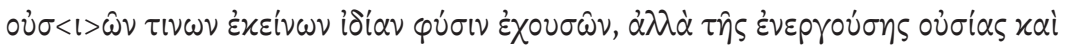

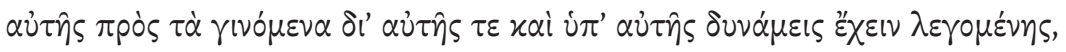
$\hat{\omega} \nu \pi \varepsilon \dot{\varepsilon} \varphi v x \varepsilon \delta \rho \alpha \hat{\nu} .{ }^{27}$

26 Cf. Frede 2003, 94 and Tieleman 2003 on Galen's use of these terms in their relation to previous Platonist tradition.

27 While it is attractive to speculate on particular people Galen might have had in mind

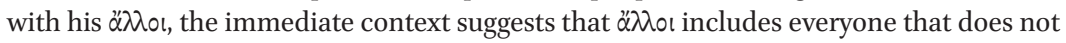
accept either incorporeal substances or incorporeal capacities that inhabit substances as the cause of activities considered psychic. Those that define the particular nature of the body in terms of mixture of the four elements, in terms of atoms or in fact any other equivalent, are all included in this category it seems, as long as they maintain that it is this particular nature itself that is the cause of the activity from which we infer soul, rather than another substance or capacity capable of existing by its own. 
And according to others [the soul] does not have some existence of its own, but the particular nature of the substance of the body is said to have capacities of those things which it does naturally, since it is not the case that the capacities possess the particular nature of certain substances, but rather the substance that is acting is said to have capacities for the things which it does naturally with regard to the things that happen through it and because of it.

Again, we find the view that it is the bodily substance, and its peculiar nature, that is the cause of the activity on the basis of which we infer the existence of soul. In this view, it is really the particular constitution of the substance of the body itself that is cause, rather than any capacity that follows from itremember Galen's objection to the position of Andronicus in $Q A M$.

Galen, interestingly, proceeds to state after his enumeration of the various possible positions that he has positioned himself somewhere midway in this discussion: on some other subjects he has spoken clearly, some of which he has known the truth of, and some of which he did not know anything at all, but in the discussion at hand he goes as far as stating what is plausible $(\pi(\theta \alpha \nu \circ \hat{)})$, although he thinks that it would be better to have a sure knowledge on this subject. Therefore, it seems to me that we should understand the 'middle position' that Galen says he has been taking, to refer to the epistemological status of his position in this debate, rather than to a position in between the actual views of the soul being incorporeal or not having a separate substance. As to those views, it is clear enough, I think, from the nearly complete correspondence between what is said in QAM and Prop. Plac. on the subject, where Galen's sympathies lie - namely with the view that the soul (i.e. the cause of activity) does not have a separate existence and is rather a bodily mixture-but he simply qualifies this subject as (currently) outside the domain of things he knows for certain, and considers his views on the matter to be plausible rather than having the status of certain knowledge. ${ }^{28}$ That does not mean, however, that he does not find his position more plausible than that of someone who holds that the soul is a separate incorporeal substance inhabiting the body and it

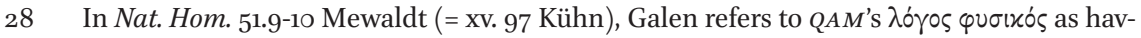
ing no little plausibility (ov่ $\sigma \mu \iota x \rho \dot{\alpha} \nu$ है $\chi \omega \nu \pi i \theta \alpha \nu o ́ \tau \eta \tau \alpha)$. Nemesius' analysis of Galen (with what looks like reference to $Q A M$, cf. Sharples and van der Eijk 2008 ad loc.) might be close our reading: he did not make a decisive or definitive statement on the soul, but it seems as

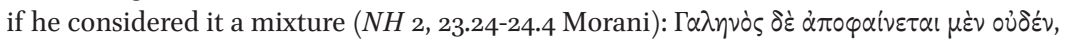

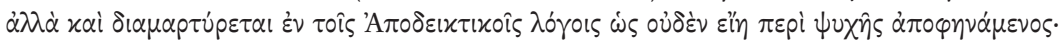

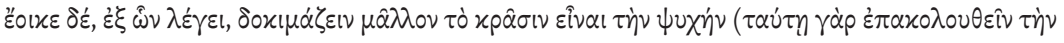

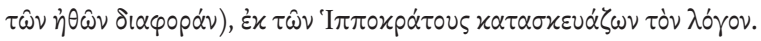


certainly does not mean that he has no view on the subject altogether. It means that Galen has an opinion on what the substance of soul is, that builds on his previous work as well as on what he considers to be the observational evidence, but that cannot (yet) be proven in a conclusive scientific manner. With regard to $Q A M$, I think that, more than anything else, it is Galen's exploration of what he considers to be a plausible view with regard to the tricky subject of the substance of the soul. ${ }^{29}$

\section{Editions}

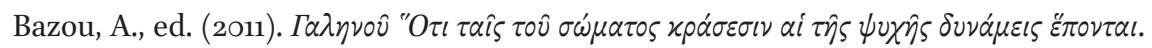
Athens.

Boudon-Millot, V. and Pietrobelli, A., eds. (2005). Galien ressuscité. Edition princeps du texte grec du De Propriis Placitis. Revue des Études Grecques 118, pp 168-213.

De Lacy, P. H., ed. (1996). Galeni de elementis ex hippocratis sententia, CMG V 1, 2. Berlin. Garofalo, I. and Lami, A., eds. (2012). Galeno, l'anima e il dolore. De indolentia; De propriis placitis. Milan.

Kühn, C. G., ed. (1821-1833). Claudii Galeni Opera Omnia. Hildesheim.

Mewaldt, J., ed. (1914). Galeni in Hippocratis De natura hominis. CMG v. 9.1. Leipzig.

Morani, M., ed. (2018). La natura dell'uomo, Nemesio di Emesa. Bologna.

Müller, I., ed. (1967). Claudii Galeni Pergameni Scripta Minora. Vol. 2. Amsterdam.

\section{References}

Barnes, J. and Jouanna, J., eds. (2003). Galien et la philosophie. Entretiens sur l'antiquité classique 49. Geneva.

Brock, A. J., tr. (1916). Galen. On the Natural Faculties. Cambridge.

Chiaradonna, R. (2014). Galen on what is Persuasive (pithanon) and what Approximates Truth. In: P. Adamson, R. Hansberger and J. Wilberding, eds., Philosophical Themes in Galen. London, pp. 61-88.

Chiaradonna, R. (unpublished). Aspects of Causation in Galen's Work on Pulse.

Caston, V. (1997). Epiphenomenalisms, Ancient and Modern. The Philosophical Review 106, pp. 309-63.

29 The research which resulted in this paper has been made possible through a grant from the Netherlands Organization for Scientific Research (Nwo) for the project 'Human Nature: Medical and Philosophical Perspectives in the Work of Galen of Pergamum'. 
Daremberg, C. V., ed. (1848). Fragments du commentaire de Galien sur le Timée de Platon. Paris.

Das, A. (2014). Reevaluating the Authenticity of the Fragments from Galen's On the Medical Statements in Plato's Timaeus (Scorialensis Graec. $\Phi$-III-11, ff. $123^{\mathrm{r}}-126^{\mathrm{v}}$ ). Zeitschrift für Papyrologie und Epigraphik 192, pp. 93-103.

Donini, P. L. (2008). Psychology. In: R. J. Hankinson, ed., The Cambridge Companion to Galen (Cambridge), pp. 184-209.

Frede, M. (2003). Galen's Theology. In: Barnes and Jouanna 2003, pp. 73-130.

Garcia-Ballester, L. (1988). Soul and Body, Disease of the Soul and Disease of the Body in Galen's Medical Thought. In: P. Manuli and M. Vegetti, eds., Le opera psicologiche di Galeno (Naples), pp. 44-63.

Hankinson, R. J., tr. (1991). Galen, On the Therapeutic Method, books I and II. Oxford.

Hankinson, R. J. (2003). Causation in Galen. In Barnes and Jouanna 2003, pp. 31-72.

Hankinson, R. J. (2006). Body and Soul in Galen. In: R. A. H. King, ed., Common to Body and Soul (Berlin), pp. 232-58.

Hankinson, R. J. (2008). Philosophy of Nature. In: Hankinson, ed., The Cambridge Companion to Galen (Cambridge), pp. 210-41.

Hankinson, R. J. (2014). Galen and the Ontology of Powers. British Journal for the History of Philosophy 22, pp. 951-73.

Hankinson, R. J. (2017). Substance, Element, Quality, Mixture: Galen's Physics and his Hippocratic Inheritance. Aitia 7.2. U RL: http://journals.openedition.org/aitia/1863.

Hankinson, R. J., tr. (forthcoming). Galen, Commentary on Hippocrates' Nature of Man. Oxford.

Havrda, M. (2017). Body and Cosmos in Galen's Account of the Soul. Phronesis 62, pp. 69-89.

Kupreeva, I. (2014). Galen's Theory of Elements. In: P. Adamson, R. Hansberger and J. Wilberding, eds., Philosophical Themes in Galen (London), pp. 153-196.

Lloyd, G. E. R. (1988). Scholarship, Authority and Argument in Galen's Quod animi mores. In: P. Manuli and M. Vegetti, eds., Le opera psicologiche di Galeno (Naples), pp. 11-42.

Marechal, P. (2019). Galen's Constitutive Materialism. Ancient Philosophy 39, pp.191-209. Moraux, P. (1973). Der Aristotelismus bei den Griechen von Andronikos bis Alexandervon Aphrodisias. Vol. 2. Berlin.

Schröder, H. and Kahle, P., eds. (1934). Galeni in Platonis Timaeum commentarii fragmenta. CMG I supplementum. Leipzig: Teubner.

Sedley, D. N. (2011). Matter in Hellenistic Philosophy. In: D. Giovannozzi and M. Veneziani, eds., Materia: (Rome), pp. 53-66.

Sharples, R. W. and van der Eijk, P. J., trs. (2008). Nemesius, On the Nature of Man. Liverpool. 
Singer, P. N., tr. (1997). Galen. Selected Works. Oxford.

Singer, P. N., tr. (2013). Galen: Psychological Writings. New York.

Strohmaier, G. (1970). Über die Verschiedenheit der homoiomeren Körperteilen. CMG 3 Supplementum Oriëntale. Berlin.

Tieleman, T. (2003). Galen's Psychology. In: Barnes and Jouanna 2002, pp. 131-70.

Tieleman, T. (2018). Galen and Doxography. In: J. Mansfeld and D. T. Runia, eds., Aëtiana IV (Leiden), pp. 452-71.

Van der Eijk, P. J., tr. (2006). Philoponus On Aristotle On the Soul 1.3-5. London.

Vegetti, M. (200o). De caelo in terram. Il Timeo in Galeno (De placitis, Quod animi). In: A. Brancacci, ed. La filosofia in età imperial (Naples), pp. 69-84. 